\title{
Transcriptomic insights into citrus segment membrane's cell wall components relating to fruit sensory texture
}

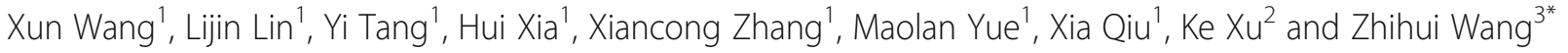

\begin{abstract}
Background: During fresh fruit consumption, sensory texture is one factor that affects the organoleptic qualities. Chemical components of plant cell walls, including pectin, cellulose, hemicellulose and lignin, play central roles in determining the textural qualities. To explore the genes and regulatory pathways involved in fresh citrus' perceived sensory texture, we performed mRNA-seq analyses of the segment membranes of two citrus cultivars, Shiranui and Kiyomi, with different organoleptic textures.
\end{abstract}

Results: Segment membranes were sampled at two developmental stages of citrus fruit, the beginning and end of the expansion period. More than 3000 differentially expressed genes were identified. The gene ontology analysis revealed that more categories were significantly enriched in 'Shiranui' than in 'Kiyomi' at both developmental stages. In total, 108 significantly enriched pathways were obtained, with most belonging to metabolism. A detailed transcriptomic analysis revealed potential critical genes involved in the metabolism of cell wall structures, for example, GAUT4 in pectin synthesis, CESA1, 3 and 6, and SUS4 in cellulose synthesis, CSLC5, XXT1 and XXT2 in hemicellulose synthesis, and CSE in lignin synthesis. Low levels, or no expression, of genes involved in cellulose and hemicellulose, such as CESA4, CESA7, CESA8, IRX9 and IRX14, confirmed that secondary cell walls were negligible or absent in citrus segment membranes. A chemical component analysis of the segment membranes from mature fruit revealed that the pectin, cellulose and lignin contents, and the segment membrane's weight (\% of segment) were greater in 'Kiyomi'.

Conclusion: Organoleptic quality of citrus is easily overlooked. It is mainly determined by sensory texture perceived in citrus segment membrane properties. We performed mRNA-seq analyses of citrus segment membranes to explore the genes and regulatory pathways involved in fresh citrus' perceived sensory texture. Transcriptomic data showed high repeatability between two independent biological replicates. The expression levels of genes involved in cell wall structure metabolism, including pectin, cellulose, hemicellulose and lignin, were investigated. Meanwhile, chemical component contents of the segment membranes from mature fruit were analyzed. This study provided detailed transcriptional regulatory profiles of different organoleptic citrus qualities and integrated insights into the mechanisms affecting citrus' sensory texture.

Keywords: Cell wall components, Citrus, Fruit develop, RNA-seq, Segment membrane, Sensory texture

\footnotetext{
*Correspondence: wangzhihui318@126.com

${ }^{3}$ College of Horticulture, Sichuan Agricultural University, No 211 Huimin

Road, Wenjiang District, Chengdu 611130, Sichuan, China

Full list of author information is available at the end of the article
}

(c) The Author(s). 2018 Open Access This article is distributed under the terms of the Creative Commons Attribution 4.0 International License (http://creativecommons.org/licenses/by/4.0/), which permits unrestricted use, distribution, and reproduction in any medium, provided you give appropriate credit to the original author(s) and the source, provide a link to the Creative Commons license, and indicate if changes were made. The Creative Commons Public Domain Dedication waiver (http://creativecommons.org/publicdomain/zero/1.0/) applies to the data made available in this article, unless otherwise stated. 


\section{Background}

Fruit quality is determined by many attributes. The organoleptic properties are the vital quality attributes that influence consumer appeal [1]. Among the organoleptic properties, texture is a major factor [2] that governs more than $30 \%$ of food palatability [3]. The sensory texture of food has been divided mechanically into several parameters, such as hardness, cohesiveness, brittleness and chewiness [4]. In fruit and vegetables, crispy and crunchy textures are particularly qualities desired by consumers because they contribute to enjoyment [5].

Plant cell walls play a central role in determining the textural quality of plant-based foods [6]. Fruit texture is primarily derived from the composition of cell walls and the middle lamella [7]. The main chemical components of plant cell walls and the middle lamella include pectin, cellulose, hemicellulose and lignin. The relative composition of the wall varies in different species, organs, tissues and cells, and is associated with plant growth, development, maturation and senescence. Edible plant tissues are usually rich in parenchymatous cells that contain mostly primary cell walls $[8,9]$. In the primary wall, the cellulose consists of $\beta$-1,4-linked glucose, with a lower degree of polymerization, between 2000 and 6000 units, rather than the over 10,000 units in secondary cell walls. Cellulose imparts rigidity and tearing resistance to edible tissues [9]. The cell walls contain two other groups of branched polysaccharides, the pectins and hemicelluloses. Pectic polysaccharides are rich in galacturonic acid, and additionally contain rhamnose, arabinose and galactose in significant amounts. Pectins are also the major components of the middle lamella. Hemicelluloses are a diverse group of polysaccharides, in which xyloglucans are the prominent hemicelluloses in the primary walls of the edible vegetables and fruit of dicotyledonous plants [6]. Pectins and hemicelluloses confer plasticity and the ability to stretch [9]. Lignin is absent, or in very low concentrations, in the cells of fruit pulp and vegetables at their edible stages $[6,9]$. Lignin affects the rigidity and cohesion of the walls [6].

Citrus fruit are hesperidia. The fruit are divided internally into 9-14 juice vesicle-containing segments by segment membranes [10]. Fresh citrus (mainly oranges and tangerines) consumption of both the flesh and segment membrane is predominant in many countries, including China, Mexico, India, Argentina and Brazil. Segment membranes are edible but non-target elements that have diverse properties among species. Generally, the segment membranes of orange are thin and with a low occurrence in the fibered pith. The neighboring segment membranes adhere tightly and are difficult to separate. In contrast, the segment membranes of tangerine are thicker and occur more often in the pith. The neighboring segment membranes are relatively easy to separate.
Segment membrane properties significantly affect the organoleptic qualities of fresh citrus, making the fruit flimsy, crispy and easy to crumble, or harsh, viscous, gummy and difficult to crumble.

In recent years, citrus hybrid cultivar production has rapidly expanded in China with the focus on consumerdesired properties, such as juiciness, sweet and seedless flesh, and easy peeling. Citrus unshiu Marcov $\times$ Citrus sinensis Osbeck (Kiyomi tangor) and Citrus reticulata Blanco 'Shiranui' are two citrus hybrid cultivars that are rapidly increasing in popularity. 'Kiyomi' is an orangemandarin cross, while 'Shiranui' is a three-way hybrid between 'Kiyomi' and C. reticulata Blanco 'Ponkan' [11]. The two cultivars are both easy to peel, sweet, juicy and seedless. However, the 'Kiyomi' fruit's texture is disagreeable. Its segment membranes are thick, glutinous and chewy. Thus, domestic consumers tend to peel off segment membranes with their hands and eat the flesh only. In contrast, 'Shiranui' fruit has a more agreeable texture. We hypothesize that the organoleptic differences in the two cultivars' segment membranes are associated with the composition of cell walls and the middle lamella. However, little is understood about this association and the underlying molecular mechanisms.

Here, to explore the molecular mechanisms of segment membrane' development, we performed an RNAseq analysis. Segment membranes were sampled at two developmental stages. The genes in the biosynthesis and regulatory pathways involved in determining the composition of cell walls and the middle lamella were emphasized. To clarify the putative association between cell wall composition and the differences in the two cultivars' organoleptic properties, the major components in the mature fruit's segment membranes were analyzed. The transcriptome analysis of segment membrane development combined with cell wall composition analyses should enhance our understanding of the effects of segment membranes on citrus organoleptic qualities.

\section{Methods \\ Plant materials and RNA preparation}

Five-year-old 'Kiyomi' tangor and 'Shiranui' trees cultivated in a citrus research orchard located in Suining, Sichuan Province, China, were used. Fruit samples were harvested at two developmental stages, 150 and 210 days after flowering, assigned as first and second stages, respectively. At the first stage, fruit development occurred during the early expansion period, while at the second stage, fruit expansion had finished, and fruit reached their maximum size and began to mature. For each cultivar, fruit samples were collected from three different trees. Thus, each tree was an independent biological replicate. For RNA-seq, two independent randomly chosen biological replicates were used. Ten representative fruit 
from each tree were collected at each sampling stage. Segment membranes separated from fruit segments were immediately frozen in liquid nitrogen and kept at $-80{ }^{\circ} \mathrm{C}$ until use. Total RNA was extracted using an RNAprep Pure Plant Kit (TIANGEN, Beijing, China), which was specifically designed for materials rich in polysaccharides and polyphenolics. Extracted RNA was treated with DNase (TIANGEN, Beijing, China) to remove genomic DNA. RNA quality was surveyed by separation in $1.0 \%$ agarose gels, stained with ethidium bromide and observed by UV light.

\section{RNA-seq library construction and sequencing}

Total RNA samples from two trees of each cultivar at two developmental stages, for a total of eight samples, were used for RNA-seq library construction and sequencing. Sequencing was performed on an Illumina HiSeq 2000 platform. RNA quantity and integrity were determined using a Nanodrop 2000 (Thermo Scientific, Waltham, MA, USA) and a Bioanalyzer 2100 (Agilent Technologies, Santa Clara, CA, USA). RNA-seq libraries were constructed using the Illumina TruSeq RNA Library Prep Kit v2 (Illumina, San Diego, CA, USA) following standard protocols. Poly(A)containing transcripts were enriched from the total RNA using oligo(dT)-coated magnetic beads. For each sample, adapters with unique barcodes were ligated to the endpolished cDNA fragments. The libraries were amplified by PCR and quantitated by Qubit 2.0 (Thermo Scientific).

\section{Gene annotation, expression level comparison and differential expression analysis}

Kallisto [12] was used for quantification with default parameters. Each repeat group had a very high correlation coefficient $(r>0.97)$, and differentially expressed genes (DEGs) were identified from each comparison using edgeR [13]. DEGs were annotated with the Pfam database [14]. Gene Ontology (GO) enrichment was performed by TopGO [15], and KOBAS [16] was applied for the Kyoto Encyclopedia of Genes and Genomes [17] enrichment. Other data analyses and visualization were performed by self $\mathrm{R}$ scripts.

\section{Quantitative RT-PCR analysis}

First-strand cDNA was synthesized from total RNA using an anchored-oligo $(\mathrm{dT})_{18}$ primer with the Transcriptor First-Strand cDNA Synthesis Kit with gDNA Eraser (Aidlab, China). The Applied Biosystems StepOnePlus ${ }^{\text {TM }}$ Real-Time PCR System equipped with StepOne ${ }^{\text {tm }}$ Software V2.1 (Bio-Rad, USA) was used. The $\beta$-actin expression level was used for normalization. Water was the negative control. Each reaction was replicated three times. To confirm the specific amplification of desired PCR products, melting curves were analyzed. The qRT-PCR data were analyzed using the comparative $\Delta \Delta \mathrm{C}_{\mathrm{T}}$ method [18]. All of the reactions were performed with three biological replicates.

\section{Segment membrane' weight-ratio determination}

The weight ratios of segment membranes to whole segments of mature fruits were determined. For each cultivar, the three trees sampled for RNA-seq and qRT-PCR were used. The data from each tree were regarded as a replicate. Ten fruits were sampled from each tree. Fruit segments were separated and weighed. After carefully removing juice pulp from inside the segment, the segment membranes were weighed. The segment membrane' weight ratio was given as the value (\%) of the segment membrane to fruit segment.

\section{Pectin content and pectin methylation analysis}

The segment membranes used for weight-ratio determination were dried and ground to a 60-mesh powder. The powder was used for pectin content and pectin methylation analyses, and the following experiments, which included determinations of the lignin, cellulose and hemicellulose contents. The data from each tree were regarded as a replicate. Pectin content was determined by quantifying GalA using the carbazole colorimetric method [19]. The extent of pectin methylesterification was determined by the quantification of the released methanol $[20,21]$.

\section{Analyses of lignin, cellulose and hemicellulose contents} The lignin content was the sum of the Klason insoluble and soluble lignin. Klason insoluble lignin was analyzed according to the Tappi T 222 om-88 as described by Bura et al. [22]. Soluble lignin in hydrolysate from the Klason analysis was monitored using a UV spectrophotometer at $205 \mathrm{~nm}$. Cellulose and hemicellulose contents were calculated from glucose and xylose contents, respectively, in the Klason analysis' hydrolysate. The glucose and xylose contents were determined using highperformance liquid chromatography (Flexar, PerkinElmer, Inc., Waltham, MA, USA) with a refractive index detector. The lactose $(0.5 \mathrm{~g} / \mathrm{L}$, Sigma, USA) was used as an internal standard. Each item's measurement was repeated three times.

\section{Results and discussion}

Summary of the transcriptomic sequencing dataset and gene differential expression levels

Total RNAs from eight samples (two citrus cultivars sampled at two developmental stages were performed two biological replicates) were prepared and sequenced on an Illumina HiSeq 2000 platform. The output was an average $10 \mathrm{M}$ reads (Paired-end 100-bp model) for each library. High repeatability was shown between two independent biological replicates. From a principal component analysis (Fig. 1), the eight samples were clearly 


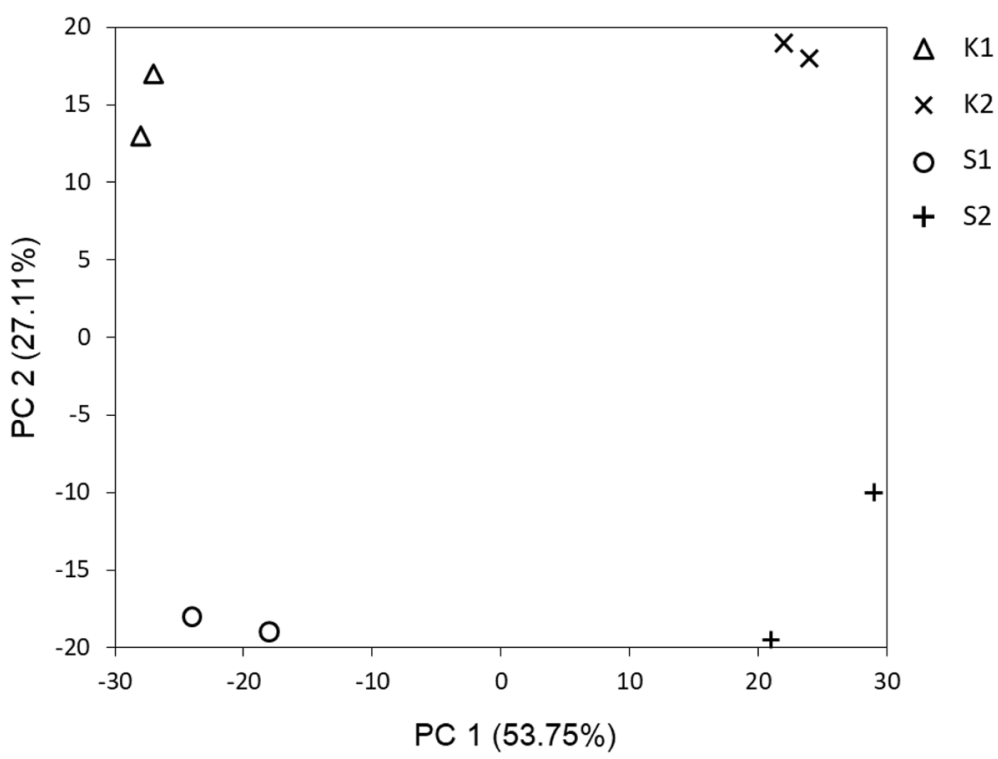

Fig. 1 Principal component analysis of gene expression. K1: 'Kiyomi' at first stage; K2: 'Kiyomi' at second stage; S1: 'Shiranui' at first stage; S2: 'Shiranui' at second stage

separated in the first principal component $(\mathrm{PC}) 1 \times \mathrm{PC} 2$ score plots. The total variable of $\mathrm{PC} 1$ reached to $53.75 \%$, and PC1 was clearly separated between two developmental stages. The total variable of PC2 was $27.11 \%$ and was separated between the two cultivars.

All transcriptomes and unigenes were realigned. Read counts were normalized by transcripts per million, and the $R$ package's edgeR was used to call DEGs. The DEG cut-offs were a false discovery rate (FDR) $<0.005$ and an absolute $\log _{2}$ fold change $>1$. A DEG-based heatmap was supplied in Additional file 1: Figure S1. More than 3000 DEGs were identified. The numbers of DEGs in the four comparisons were listed in Table 1.

Eight DEGs were used in a qRT-PCR assay to further validate the transcriptome sequencing dataset. Primers used in quantitative RT-PCR experiments were listed in Additional file 1: Table S1. The comparison of the qRTPCT analysis to RNA-seq expression levels was provided in Additional file 1: Figure S2. Positive correlations were exhibited in the four sample comparisons, showing $\mathrm{R}^{2}$ to be 0.5413 ('Kiyomi' first-stage vs. 'Shiranui' first-stage), 0.7469 ('Kiyomi' second-stage vs. 'Shiranui' second-stage), 0.5313 ('Kiyomi' first-stage vs. 'Kiyomi' second-stage), and 0.7893 ('Shiranui' first-stage vs. 'Shiranui' second-stage).

\section{Determination of biological processes and pathway enrichment}

The GO enrichment analysis identified 76 GO categories as significantly enriched at the first stage, including 67 categories in 'Shiranui' and 33 in 'Kiyomi', with 24 categories that overlapped. At the second stage, in agreement with the biological processes majority in 'Shiranui' at the first stage, 72 categories were identified to be significantly enriched in 'Shiranui' and 42 in 'Kiyomi', with 28 categories overlapped, and totally $86 \mathrm{GO}$ categories were significantly enriched at the second stage. In comparisons between the different developmental stages of each cultivar, the GO-enrichment analysis identified 131 biological processes as significantly enriched in 'Kiyomi', with 93 processes at both the first and second stages, and 55 overlapping processes. In 'Shiranui', 112 processes were enriched, 77 at the first stage and 80 at the second stage, with 45 overlapping processes.

A total of 108 significantly enriched pathways were obtained. At the first stage, 67 and 36 pathways were enriched in 'Shiranui' and 'Kiyomi,', respectively. Similarly, at the second-stage, 63 and 42 pathways were enriched in 'Shiranui' and 'Kiyomi', respectively. The top 30 significantly enriched pathways in 'Kiyomi' or 'Shiranui' were shown in Additional file 1: Figure S3. At the first stage, the pathways "glycolysis/gluconeogenesis", "pyrimidine metabolism" and "plant hormone signal transduction" were the most significantly enriched in 'Kiyomi'. In 'Shiranui', all of the pathways

Table 1 Number of differentially expressed genes

\begin{tabular}{ll}
\hline Sample comparisons & Number of different expression genes \\
\hline K1 vs. S1 & 575 \\
K2 vs. S2 & 649 \\
K1 vs. K2 & 1578 \\
S1 vs. S2 & 1205 \\
\hline
\end{tabular}

K1 and K2: 'Kiyomi' samples from first and second developmental stages, respectively; S1 and S2: 'Shiranui' samples from first and second developmental stages, respectively 
indicated similar and relatively low levels of enrichment. At the second stage, "peroxisome" was highly significantly enriched in 'Kiyomi', and "photosynthesis-antenna proteins", "plant-pathogen interaction" and "circadian rhythm-plant" were significantly enriched in 'Shiranui'. Pathways were grouped according to KEGG pathway maps (http://www. genome.jp/kegg/pathway.html). Most pathway groups belonged to the metabolism category, including "carbohydrate metabolism", "energy metabolism", "lipid metabolism", "amino acid metabolism", "metabolism of cofactors and vitamins" and "metabolism of terpenoids and polyketides" (Additional file 1: Figures S3-S6). DEGs in the metabolism category were presented in Fig. 2.

Comparing the different developmental stages, 74 and 72 enriched pathways were identified at the first and second stages, respectively, in 'Kiyomi', while in 'Shinarui', 67 enriched pathways were identified at both the first and second stages. The top 30 significantly enriched pathways at the first and second stages were shown in Additional file 1: Table S2.

The cell wall bestows rigidity to the plant and texture to plant tissues, and the cellular components are possibly responsible for the taste and texture of citrus segment membranes. In growing plants, the major cell wall components are cellulose, hemicellulose, pectin, lignin and a small amount of structural proteins. Cellulose, hemicellulose and pectin are carbohydrates, which impart cell-wall rigidity, increase tensile strength and provide the ability to resist compression. Lignin, a polymer of aromatic alcohols, is hard and renders considerable strength to the cell wall. Enriched pathway results reinforced these conclusions. For example, in the carbohydrate metabolism group, which was frequently enriched, "starch and sucrose metabolism", "amino sugar and nucleotide sugar metabolism" and "pentose phosphate pathway", were key pathways responsible for the synthesis and degradation of pectin, cellulose and hemicellulose. Accordingly, we investigated the expression levels of genes involved in the metabolism of cell wall structures.

\section{Pectin metabolism-related transcriptomic insights}

Pectins are a group of polysaccharides predominantly composed of GalA. Homogalacturonan (HG), the homopolymer of GalA (D-GalA) linked in an $\alpha-1,4$ configuration, is the most abundant pectic polysaccharide. HG biosynthesis is catalyzed by $\alpha-1,4-\mathrm{D}$-galacturonosyltransferase (EC 2.4.1.43), designated GAUT, and some GAUTlike (GATL) proteins [23]. Twelve GAUTs, GAUT1-15, with the exception of GAUT2, 5 and 13, were detected in our research. GAUT4, 8, 9 and 15 showed slightly higher expression levels than other GAUTs, with the average expression levels from the two citrus cultivars at both developmental stages being greater than 10 (Additional file 1: Table S3). No differential expression of the four genes was found between 'Kiyomi' and 'Shiranui' at either the first or second stage, with the exceptions that GAUT4 and GAUT8 were expressed significantly higher $(p<0.05)$ in the second stage than in the first stage in both cultivars. GAUT1 and GAUT7 showed similar and relatively low expression levels (Additional file 1: Table S3). Arabidopsis GAUT4- and GAUT1-encoding proteins were confirmed as crucial to plant growth and development, and their mutations may be lethal [23]. Here, citrus GAUT4 and GAUT1 also showed detectable levels, indicating these potentially crucial roles. GAUT4 was expressed more highly among the GAUT genes, suggesting its important role in citrus. The similar expressing patterns of GAUT1 and GAUT7 in our results might be explained by their functioning in a protein complex [24]. GAUT2 was not detected in either 'Kiyomi' or 'Shiranui', which was in agreement with GAUT2 being a nonfunctional truncated homolog of GAUT1 [25]. Several GAUT-like genes were detected, including GATL2-10, with the exception of GATL6 and GATL8. The expression levels of the GATLs were similar to those of the GAUT genes (Additional file 1: Table S3).

There is a group of pectinases that broadly control pectin degradation. Pectin methylesterase (PME, E.C. 3. 1.1.11) is an enzyme that catalyzes the specific hydrolysis of the methyl ester bond at C-6 in GalA residues in the linear HG domain of pectin, which is secreted in a highly (70\%-80\%) methylesterified form. In total, 23 integral $P M E$ isoform genes were detected in this research. Several $P M E$ s showed higher expression levels than the HG biosynthesis-related GAUT and GATL genes. For instance, the average PME31 expression level from 'Kiyomi' and 'Shiranui' at the two developmental stages was 276.333 , which was significantly higher than that of GAUT8 (17.261) or GATL3 (16.460). PME transcripts displaying expression levels greater than 10 were listed in Additional file 1: Table S3, and there were 11 transcripts in total. At the first stage, 8 of the $11 P M E \mathrm{~s}$ showed higher expression levels in 'Shiranui' than in 'Kiyomi' (Fig. 3; Additional file 1: Table S3), but at the second stage, only 6 PMEs had higher expression levels (Fig. 3; Additional file 1: Table S3). The PMEs tended to be expressed higher in the second stage than in the first stage. In 'Kiyomi', 9 of 11 PMEs had increased expression levels in the second stage (Fig. 3; Additional file 1: Table S3), while in 'Shiranui' 7 had increased expression levels in the second stage (Fig. 3; Additional file 1: Table S3). PMEs have diverse functions in plant growth, and their transcripts and protein activities are likely to involve the recruitment of pools of specific isoforms [26]. The roles of PMEs are linked to cell wall extension and stiffening, cellular separation, dry fruit dehiscence and soft fruit ripening [27]. The PMEs detected in our research were predicted to be involved in at least two processes, cell 
a

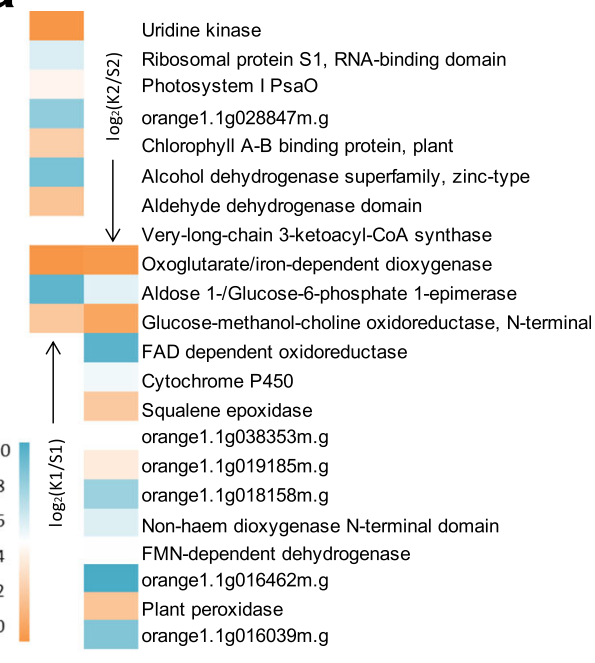

b

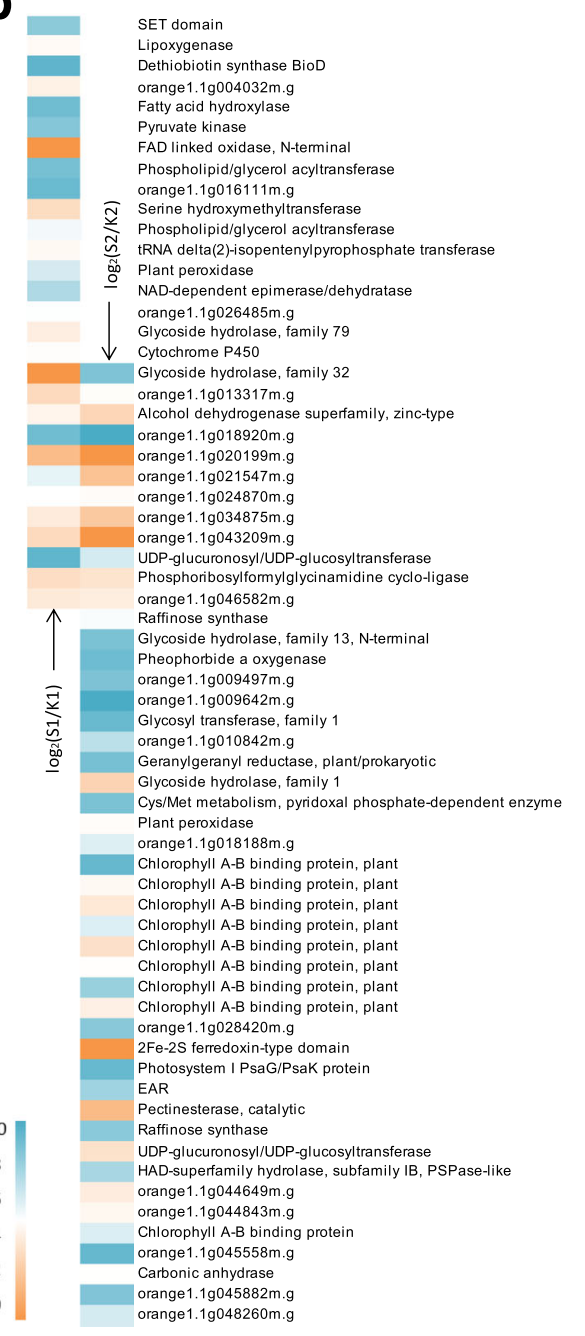

Fig. 2 Up-regulated genes in KEGG metabolism category in the comparison of 'Kiyomi' to 'Shiranui' (a) and in the comparison of 'Shiranui' to 'Kiyomi' (b). The orange-to-blue scale represents a decreasing $\log _{2}$-fold change of gene expression. K1/S1: the comparison of 'Kiyomi' to 'Shiranui' at the first stage; K2/S2: the comparison of 'Kiyomi' to 'Shiranui' at the second stage; S1/K1: the comparison of 'Shiranui' to 'Kiyomi' at the first stage; S2/K2: the comparison of 'Shiranui' to 'Kiyomi' at the second stage

wall extension and fruit ripening. The multiple roles of PMEs might explain why PMEs were generally expressed to greater extents than the GAUTs and GATLs. A similar result was observed in a tomato (Solanum lycopersicum) study, in which gene expression was visually analyzed on ethidium bromide-stained gels [28].

A number of genes encoding PME inhibitor (PMEI) family proteins, which restrain PMEs through a posttranslational control mechanism, were also detected in this research. There were nine PMEI contigs that had expression levels greater than 10 (Additional file 1: Table S3). The expression levels of PMEIs were comparative to, or even higher than, those of the PMEs (Additional file 1: Table S3).

Seven genes encoding pectin acetylesterase (E.C. 3.1.1.6), which is responsible for removing the acetyl residues of pectin, were found in our research. The pectin acetylesterase 8, 2 and 6 genes had expression levels greater than 10 and were listed in Additional file 1: Table S3.

The deesterified pectin is subsequently degraded by pectinases that break the $\alpha-1,4$-linkages. Pectinases function by hydrolysis, such as polygalacturonase (E.C. 3.2.1.15), or through transelimination mechanisms, such as pectate lyase (E.C. 4.2.2.2) and pectin lyase (E.C. 4.2.2.10). Here, 32 independent contigs belonging to the pectinase superfamily were detected, although the gene names of these contigs were not annotated by querying using a BLAST algorithm-based search against Arabidopsis protein databases. Twelve contigs, with expression levels greater than 10 in any sample, were shown in Additional file 1: Table S3. The levels of pectinase activity in the first and second stages might not have been as great as those of the GAUTs, GATLs and PMEs.

\section{Cellulose metabolism-related transcriptomic insights}

Cellulose is a linear homopolymer of $\beta$-1,4-linked glucose residues in plant. Its synthesis is organized by specific plasma membrane-bound cellulose synthase (CESA; EC 2.4.1.12) complexes in symmetrical rosette forms [29]. We detected seven CESA genes, CESA1, 3, 4, 6, 7, 8 and 9, that were expressed in citrus fruit segment membranes (Additional file 1: Table S4). Among them, CESA4, 7 and 8, showed very low expression levels. The other four, CESA1, 3, 6 and 9, displayed relatively high expression levels, which all increased from the first to second stage (Fig. 4). At the first stage, the expression 


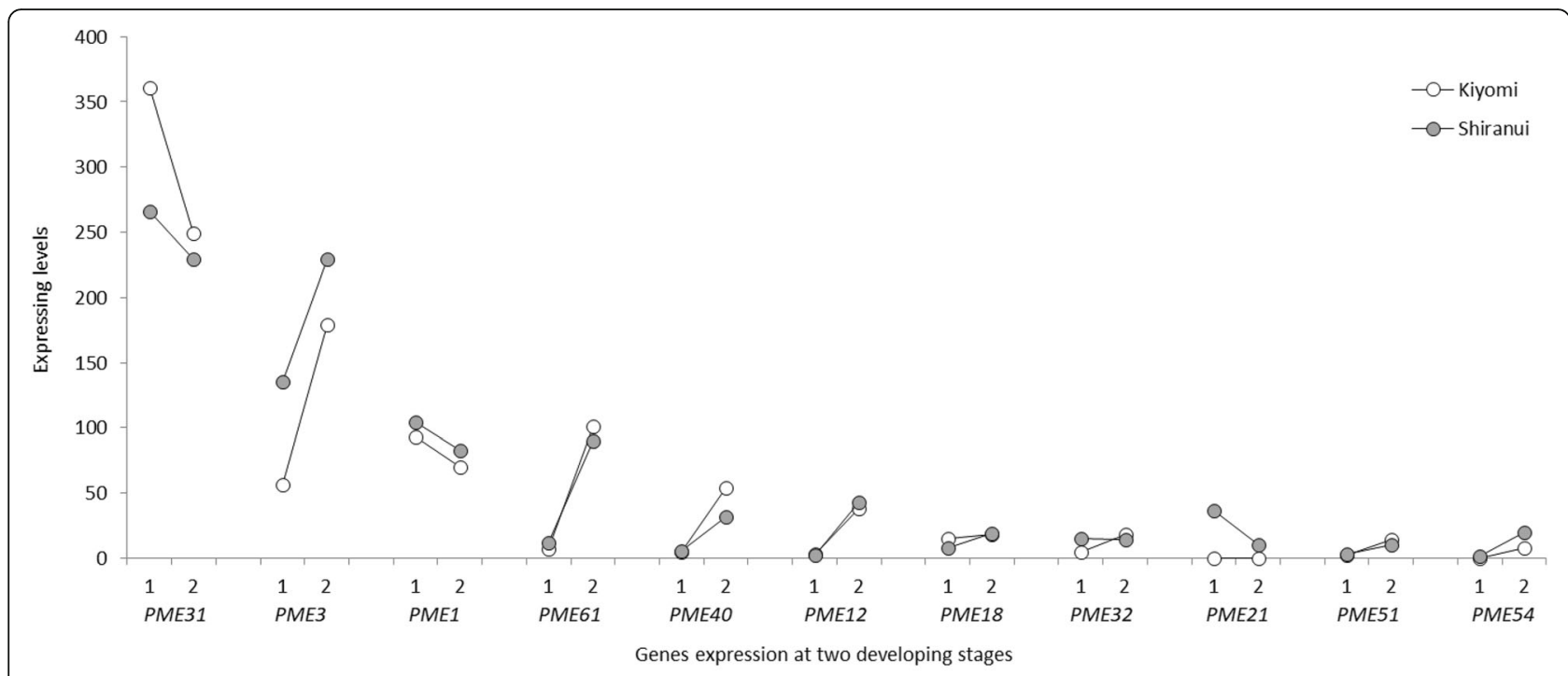

Fig. 3 PME transcript expression levels in 'Kiyomi' and 'Shiranui' at two developmental stages. 1: at the first stage; 2: at the second stage. PME genes on the $X$-axis are listed in the order of the average expression levels from highest to lowest

levels of the four genes in 'Shiranui' were all greater than in 'Kiyomi'. At the second stage, CESA9 maintained a significantly higher expression level in 'Shiranui'. CESA1 also had a higher expression level in 'Shiranui', but it was not statistically significant. CESA3 and 6 had similar expression levels in the two cultivars. The Arabidopsis genome has at least 10 CESAs [30]. Arabidopsis CESA4, 7 and 8 genes combine to form the CESA rosette required for secondary wall synthesis [31-34]. The expression patterns of the three genes were highly correlated
[35-37]. In our research, the co-expression of CESA4, 7 and 8 at low levels indicated week or negligible secondary cell-wall formation occurred in citrus segment membranes. In Arabidopsis, at least three of the four CESA proteins, CESA1, 2, 3 and 6 , are required for primary wall synthesis. CESA1 and 3 appear to be absolutely required, whereas CESA2 and 6 may be at least partially redundant [37-41]. The absence of the CESA2 gene in our results indicated the requirement for CESA1, 3 and 6 in citrus segment membranes' primary wall synthesis.

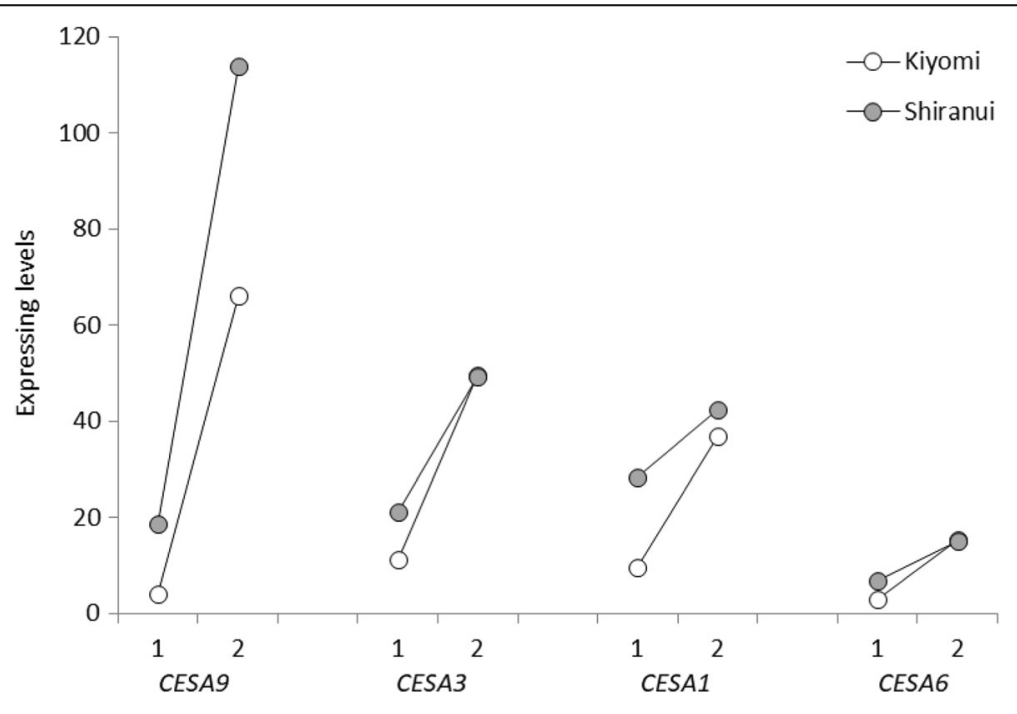

Genes expression at two developing stages

Fig. 4 CESA transcript expression levels in 'Kiyomi' and 'Shiranui' at two developmental stages. 1: at the first stage; 2: at the second stage. CESA genes on the $X$-axis are listed in the order of the average expression levels from highest to lowest 
The lower level of CESA6 relative to CESA1 and CESA3 inferred that the former is potentially redundant. Plant primary cell walls are generally thin and less rigid, whereas secondary cell walls are rigid and responsible for most of the plant's mechanical support. In mature fruit's flesh cells, primary cell walls are dominant, while secondary cell walls are virtually absent $[6,9,42]$. From the expression levels of CESAs in our research, it was confirmed that primary cell walls were dominant in citrus segment membranes.

Sucrose synthase (SUS, also SuSy; EC 2.4.1.13) is another important enzyme involved in cellulose synthesis. Four SUS-encoding genes were detected in our research. SUS3 and 4 showed significantly high expression levels comparing with those of SUS2 and 6 (Additional file 1: Table S4). The SUS4 expression increased from the first to second stage in both 'Kiyomi' and 'Shiranui' (Fig. 5). It was expressed higher in 'Shiranui' than in 'Kiyomi' at the first stage, whereas at the second stage, there was no obvious difference in its expression level between the two citrus varieties. SUS3 showed a higher expression level in 'Shiranui' than in 'Kiyomi' at both developmental stages. SUS is associated directly with the CESA complex and contributes to cellulose biosynthesis [43]. Here, citrus SUS4 had a 91\% amino acid identity with Gossypium hirsutum SuSy (GenBank U73588), which may be associated with cellulose synthesis [44]. In our transcriptome data, SUS4 displayed an expression pattern similar to those of CESA1, 3 and 6, which are associated with cellulose synthesis in primary walls. We hypothesized that SUS4 might be the main protein responsible for cellulose synthesis in citrus primary cell walls.

We detected three genes encoding cellulases (CEL; EC 3.2.1.4), including endo- $\beta$-1,4-glucanase. Compared with CESA and SUS, the expression levels of the CELs were low (Additional file 1: Table S3). CEL3 was the only one with a relatively high expression level, which increased from the first to second stage in both cultivars, and was expressed higher in 'Shiranui' at both stages. CEL genes were expressed at low levels in our experimental materials, which is in accordance with the opinion that plant cellulases actually endohydrolyze cellulose and are not strong enough to cause the bulk degradation of cellulose microfibrils [45].

Hemicellulose metabolism-related transcriptomic insights Hemicellulose is a diverse group of polysaccharides. It constitutes roughly one-third of the wall biomass. In dicots, the hemicelluloses are primarily xyloglucans (XyGs) and xylans (Xyls). The former is most abundant in the primary cell wall, and the latter in the secondary cell wall [46].

XyGs have a $\beta$-1,4-glucan backbone that is linked with different mono-, di- or trisaccharide side-chain xylosyl residues. XyG biosynthesis requires glucan synthase to form the glucan backbone and glycosyl transferases to produce

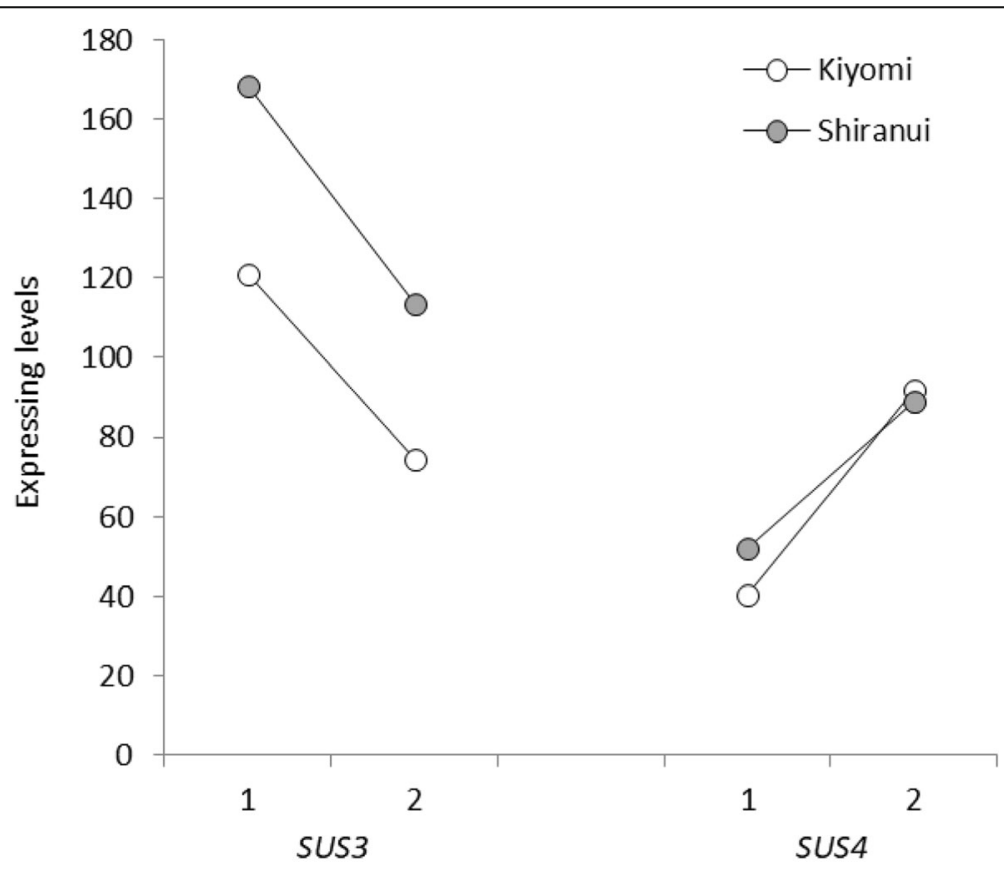

Genes expression at two developing stages

Fig. 5 SUS transcript expression levels in 'Kiyomi' and 'Shiranui' at two developmental stages. 1: at the first stage; 2: at the second stage. SUS genes on the $X$-axis are listed in the order of the average expression levels from highest to lowest 
the side chains. At least five types of enzymatic activities are involved in XyG biosynthesis: cellulose synthase-like C proteins (CSLCs), XyG xylosyltransferases (XXTs), galactosyltransferase, fucosyltransferase and acetyltransferase. All of the genes encoding these enzymes were expressed in this study (Additional file 1: Table S5). The CSLCs and XXTs are responsible for the synthesis of the glucan backbone and xylosyl residues, respectively, which are the two major components of XyGs. Three CSLC genes, CSLC4, 5 and 12, were detected in citrus segment membranes. CSLC4 and 5 showed similar but lower expression levels than CSLC12 (Fig. 6). The Arabidopsis CSLC4 functions in the homocomplex CSLC4-CSLC4 and heterocomplex CSLC4-XXT [46]. It is highly expressed in all Arabidopsis tissues, and, within a tissue, its expression was in keeping with the expression levels of XXTs and corresponded with the tissue's developmental timing $[47,48]$. Here, however, CSLC4 had a relatively low expression level, which might imply a less significant role in XyG synthesis in citrus segment membranes. CSLC5 is another important enzyme involved in the synthesis of the glucan backbone of XyG [49], but it is limited to specific tissues [47]. The similar levels of CSLC4 and 5 in our results implied complementary roles in citrus segment membranes. Another CSLC gene, CSLC12, showed a relatively higher expression level than either CSLC4 or CSLC5. Limited reports addressing CSLC12 implied that it is a potential XyG-synthesis candidate. CSLC12 was expressed in all of the tested Arabidopsis organs, including roots, stems, flowers and seedlings [50]. In addition, like the Arabidopsis CSLC12 protein, citrus CSLC12 showed high homology levels to rice CSLC 1 (identity 72\%), CSLC 7 (identity 73\%) and CSLC 9 (identity
$74 \%$ ), which are expressed during different stages of ovule development [51].

Three $X X T$ genes, $X X T 1,2$ and 3, were found in the present materials. The expression levels of XXT1 and $X X T 2$ were higher in all of the materials than the expression levels of XXT3 (Fig. 7). Five XXTs (XXT1-5) have been confirmed in Arabidopsis [52]. Among the five proteins, XXT1, 2 and 5 were confirmed to form hetero- or homo-complexes, such as XXT1-XXT2, XXT2-XXT2 and XXT2-XXT5 [46]. Additionally, in the major Arabidopsis tissues, XXT2 has an approximately twofold greater expression level than XXT1 and 5 [47]. In our data, at the second stage, XXT2 showed a twofold higher expression level than XXT1, but at the first stage its expression level was similar to that of XXT1. The connections in the XXT1-XXT2 and XXT2-XXT2 complexes may be temporal. $X X T 3$, but not $X X T 5$, was detected in our study. XXT5 is not as essential a protein for XyG formation as XXT1 and XXT2 [52], but the lack of this protein dramatically impacts XyG biosynthesis (Zabotina, 2012). In the Arabidopsis xxt5 mutant, the absence of the XXT5 protein may be compensated for by other xylosyltransferases [53]. The citrus XXT5 function may have been compensated for by XXT1, 2 or 3 . A XyG xylosyltransferase activity for XXT3 is suggested in Arabidopsis [54], which supports our hypothesis that XXT3 plays a compensating role for XXT5 in citrus.

Xyl is the major hemicellulose in the secondary walls of dicots [55], which is composed of a linear $\beta$-1,4-linked $\mathrm{D}$-xylosyl backbone with various side branches [56]. The glycosyltransferases, irregular xylem phenotype (IRX) 9, 10, 14, 9-like (-L), 14-L, 10-L, 7/fragile fiber 8, fragile

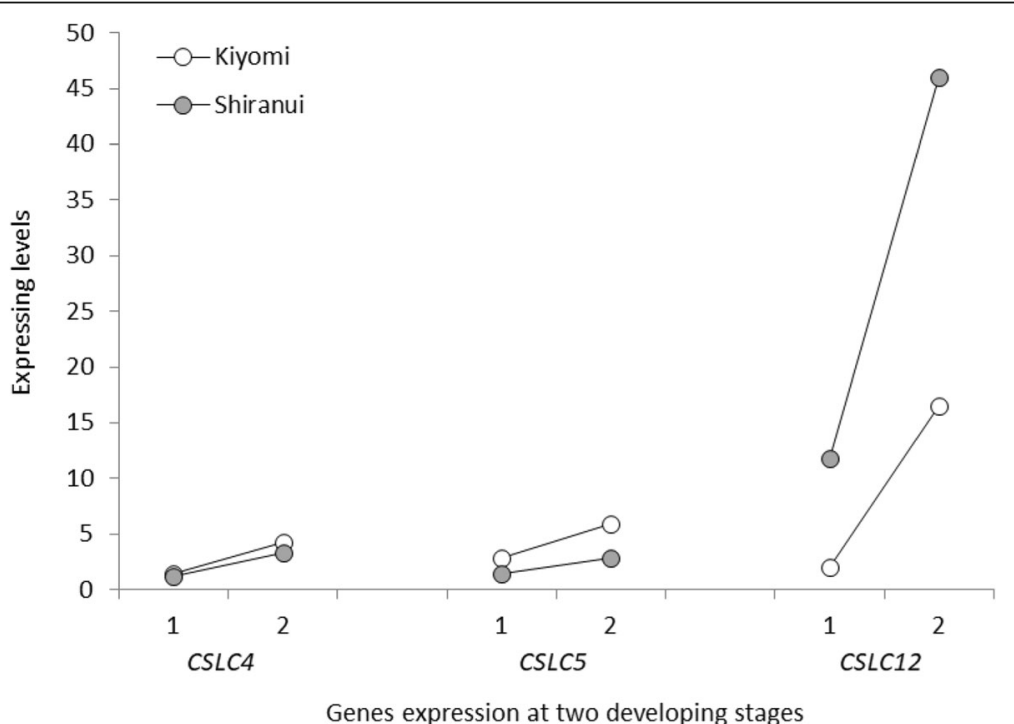

Fig. 6 CSLC transcript expression levels in 'Kiyomi' and 'Shiranui' at two developmental stages. 1: at the first stage; 2: at the second stage. CSLC genes on the $X$-axis are listed in the order of the average expression levels from highest to lowest 


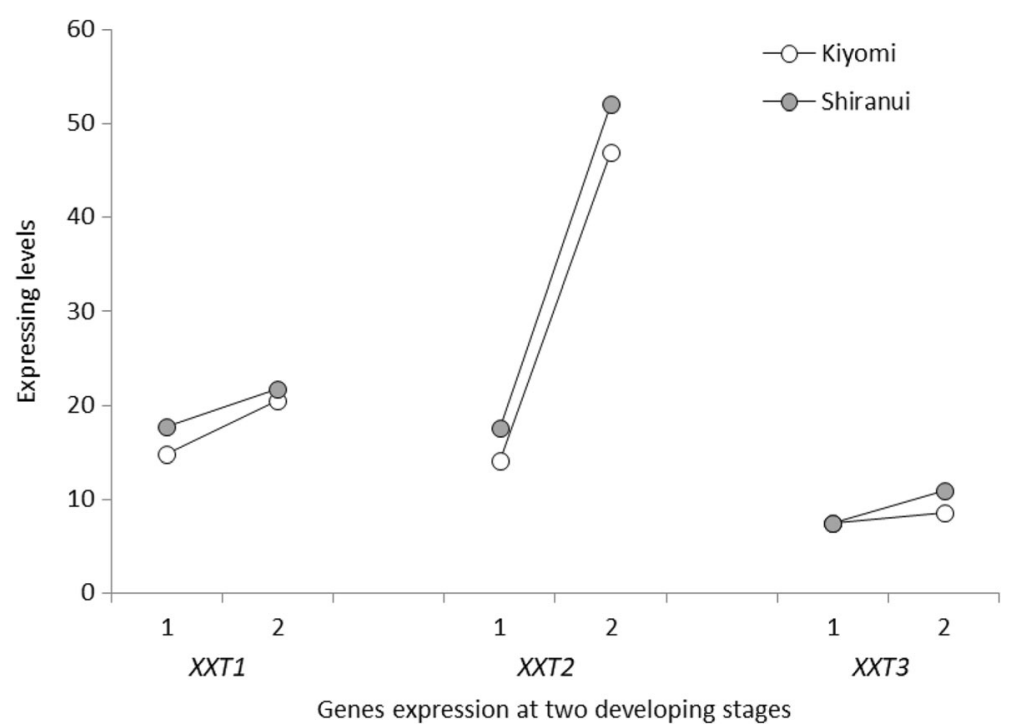

Fig. 7 XXT transcript expression levels in 'Kiyomi' and 'Shiranui' at two developmental stages. 1: at the first stage; 2: at the second stage. XXT genes on the $X$-axis are listed in the order of average expression levels from highest to lowest

fiber 8 homolog and IRX8/GAUT12, appeared to be essential for Xyl backbone synthesis, the addition of side chains and the synthesis of the reducing-end structures [56-58]. Among these proteins, IRX9, 14 and fragile fiber 8 homologs were not detected in our research (Additional file 1: Table S5). IRX9 and 14 were the only genes confirmed experimentally to have XylT activity [59-61]. IRX9- L, 14- $L$ and 10- $L$ act as partially redundant genes [55], although they are close homologs to IRX9, 14 and 10, respectively. The inability to detect IRX9 and 14 in our research suggested a low level of XylT activity and limited Xyl contents in citrus segment membranes. Because Xyl is the major hemicellulose in secondary cell walls of dicots [55], the limited Xyl content indicated weak or negligible secondary cell-wall formation. This was in accordance with the cellulose biosynthesis in which low levels of CESA4, 7 and 8, being responsible for cellulose synthesis in secondary cell walls, were detected.

\section{Lignin metabolism-related transcriptomic insights}

Lignins are complex natural polymers that result from the oxidative coupling of 4-hydroxyphenylpropanoids [62]. The synthesis of monolignols from phenylalanine requires deamination, hydroxylation, methylation and two successive reductions [63].

The synthesis of caffeoyl-CoA from phenylalanine represents a subset of the upstream steps of the lignin biosynthetic pathway, particularly coniferyl alcohol (G lignin) and sinapyl alcohol (S lignin) [63]. Six enzymes were involved in this subset, phenylalanine ammonia lyase (PAL), cinnamate 4-hydroxylase $(\mathrm{C} 4 \mathrm{H})$, 4-coumarate:CoA ligase (4CL), $p$-coumaroyl shikimate 3-hydroxylase $(\mathrm{C} 3 \mathrm{H})$, hydroxycinnamoyl
CoA:shikimate hydroxycinnamoyl transferase (HCT) and caffeoyl shikimate esterase (CSE). In our data, $P A L 1, C 4 H 2$, $4 C L 2, C 3 H 3, H C T$ (single gene) and CSE (single gene) were detected at considerable levels. After CSE, C4H2 was the highest expressed gene. Its average expression level in all eight samples was 61.683, which was greater than PAL1 (18.372), 4CL2 (38.071), HCT (9.259) and C3H3 (21.952) (Fig. 8). In Populus trichocarpa, C4H2 associates with $\mathrm{C} 3 \mathrm{H} 3$ and $\mathrm{C} 4 \mathrm{H} 1$ to form heterodimeric (C4H1-C4H2, $\mathrm{C} 4 \mathrm{H} 1-\mathrm{C} 3 \mathrm{H} 3$ or $\mathrm{C} 4 \mathrm{H} 2-\mathrm{C} 3 \mathrm{H} 3)$ and heterotrimeric $(\mathrm{C} 4 \mathrm{H} 1-\mathrm{C} 4 \mathrm{H} 2-\mathrm{C} 3 \mathrm{H} 3)$ membrane protein complexes that catalyze three converts, from cinnamic acid to $p$-coumaric acid, from $p$-coumaric acid to caffeic acid, and from $p$-coumaroyl shikimic acid to caffeoyl shikimic acid [64]. Two $\mathrm{C} 4 \mathrm{H}$ genes, $\mathrm{C} 4 \mathrm{H} 1$ and $\mathrm{C} 4 \mathrm{H} 2$, were confirmed in citrus. $\mathrm{C} 4 \mathrm{H} 2$ was constitutively expressed at a significantly higher level than C4H1, which is expressed in response to wound induction, even in wounded tissues [65]. From our data, the expression level of $\mathrm{C} 4 \mathrm{H} 2$ was extremely greater than the $0.111 \mathrm{C} 4 \mathrm{H} 1$ level, which implied that the putative heterodimeric complex of $\mathrm{C} 4 \mathrm{H} 2-\mathrm{C} 3 \mathrm{H} 3$ was preferred, rather than the complexes containing $\mathrm{C} 4 \mathrm{H} 1$. In addition, the high level of $\mathrm{C} 4 \mathrm{H} 2$ indicated that $\mathrm{C} 4 \mathrm{H} 2$ might function in both the $\mathrm{C} 4 \mathrm{H} 2-\mathrm{C} 3 \mathrm{H} 3$ complex and in $\mathrm{C} 4 \mathrm{H} 2$ alone. The CSE activity, combined with that of $4 \mathrm{CL}$, produces caffeoyl-CoA from caffeoyl shikimate, bypassing the HCT reaction that occurs in the direct conversion [66]. CSEs were highly expressed in our data, with an average value of 245.820. The high expression indicated that the CSE pathway was more effective than that of HCT, which had been suggested in Arabidopsis [66]. However, considering the significantly higher expression of CSE compared 


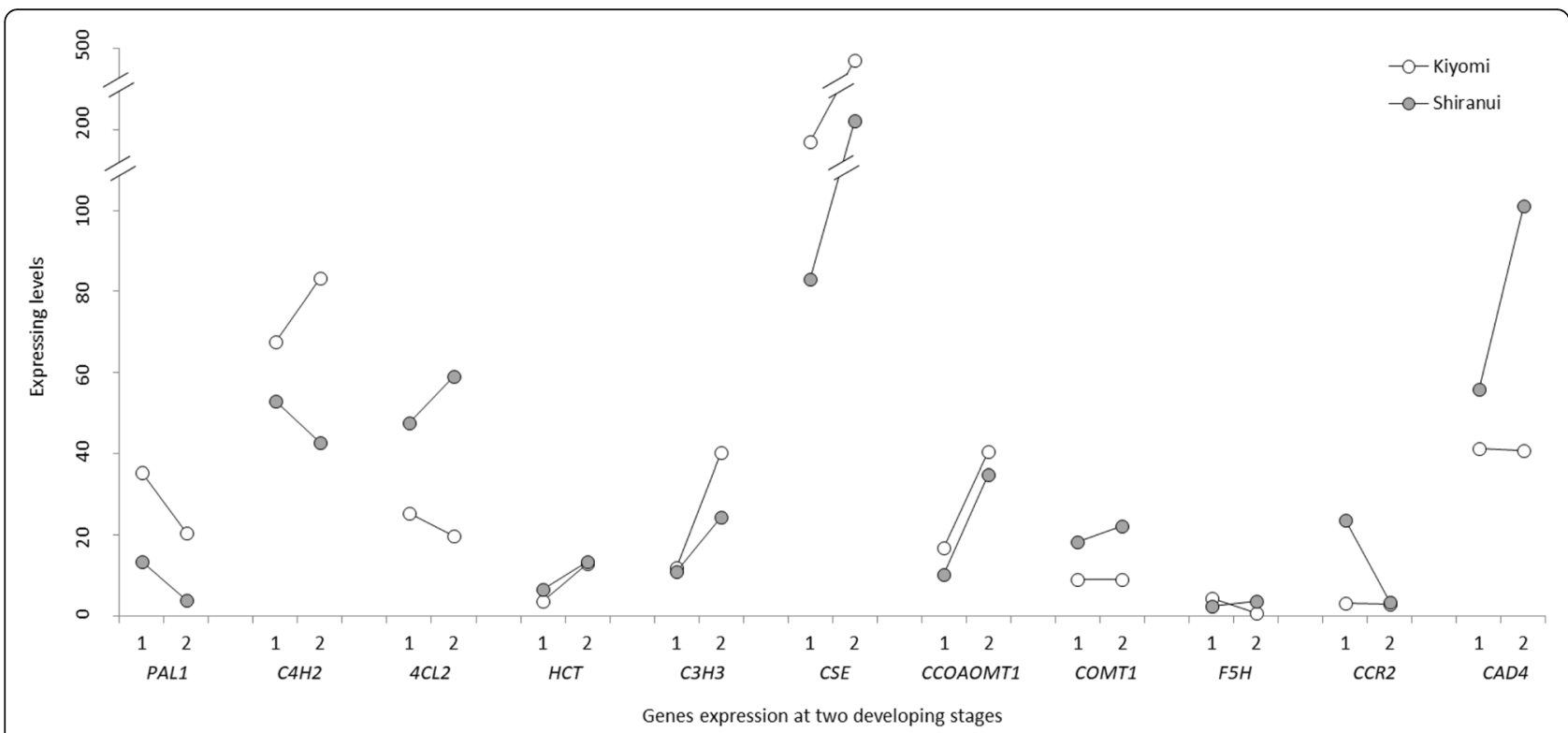

Fig. 8 Expression levels of transcripts involved in lignin biosynthesis in 'Kiyomi' and 'Shiranui' at two developmental stages. 1: at the first stage; 2: at the second stage. Genes on the $X$-axis are listed in the order of the lignin biosynthesis pathway

with other genes, it is important to try and identify additional CSE functions.

Cinnamoyl CoA reductase (CCR) and cinnamyl alcohol dehydrogenase (CAD) are responsible for the final two steps of the lignin monomer synthesis pathway. Two Arabidopsis CCRs were cloned [67, 68]. AtCCR1 is preferentially expressed in tissues undergoing lignification, while, in contrast, AtCCR2 is involved in defense responses. In our research, CCR1 showed a negligibly low expression level, with an average of 0.107 , which suggested the faint lignification of citrus segment membranes during the two developmental stages. Five $C A D$ s, $C A D 1,4$ and 7-9, were detected in the citrus segment membranes, and CAD4 (64.898 level) was more highly expressed than the others. Because the knockdown of CAD4 in Arabidopsis resulted in plants with relatively normal lignin contents [69], we did not believe that the higher CAD4 expression level would lead directly to a higher lignin content.

In addition to HCT, CSE and F5H (ferulate 5hydroxylase), other genes involved in monolignol synthesis were detected to be members of multi-gene families. The highest expressing member of each gene family was compared among citrus samples (Fig. 8). Most genes including HCT, C3H3, CCoAOMT1 (caffeoyl CoA O-methyltransferase) and COMT1 (caffeic acid O-methyltransferase), had higher expression levels at the second stage compared with the first stage in both 'Kiyomi' and 'Shiranui'. The comparisons of gene expression levels in the two citrus cultivars at the same developmental stage showed that, PAL1, $C 4 H 2, C 3 H 3, C C O A O M T 1$ and $C S E$ were expressed higher in 'Kiyomi' at both stages, while $4 C L 2, H C T, C C R 2, C A D 4$ and COMT1 were expressed higher in 'Shiranui'. The series of enzymes participating in the lignin synthesis pathway represent multiple isoforms encoded by different genes. These genes vary in kinetic properties, distributions, expression patterns, and responses to antisense suppression by the different enzyme isoforms [63]. Therefore, it is not possible to determine the specific gene responsible for the final lignin deposition. Here, in rarely lignified developing citrus segment membranes, the initial catalysis steps, e.g., the reaction catalyzed by $\mathrm{C} 4 \mathrm{H} 2$, might determine the level of lignin deposition and provide substrates for downstream reactions.

\section{Chemical component analysis in mature fruit-segment membranes}

The weight (\%) of segment membranes per segment, and the main components contents of segment membrane' cell walls, including pectin, cellulose, hemicellulos and lignin, and the degree of pectin methylesterification were illustrated in Fig. 9. The segment membrane weight of 'Kiyomi' was $15.32 \pm 0.18 \%$, which is significantly greater than that of 'Shiranui' at $8.16 \pm 1.19 \%(p<0.001)$. Among the main components of the cell wall, the pectin, cellulose and lignin contents were all greater in 'Kiyomi', especially the pectin and lignin contents, which showed significantly higher levels than in 'Shiranui'. The hemicellulose, unlike the other components, was more abundant in 'Shiranui' at $116.6 \pm 1.43 \mathrm{mg} \mathrm{g}^{-1}$ than in 'Kiyomi' at $103.2 \pm 6.15 \mathrm{mg} \mathrm{g}^{-1}(p<0.05)$. The degree of pectin methylesterification was expressed as $\mu \mathrm{CH}_{3} \mathrm{OH} \mathrm{g}^{-1}$. Based on the results (Fig. 9), 'Shiranui' was more methylesterified than 'Kiyomi'. 


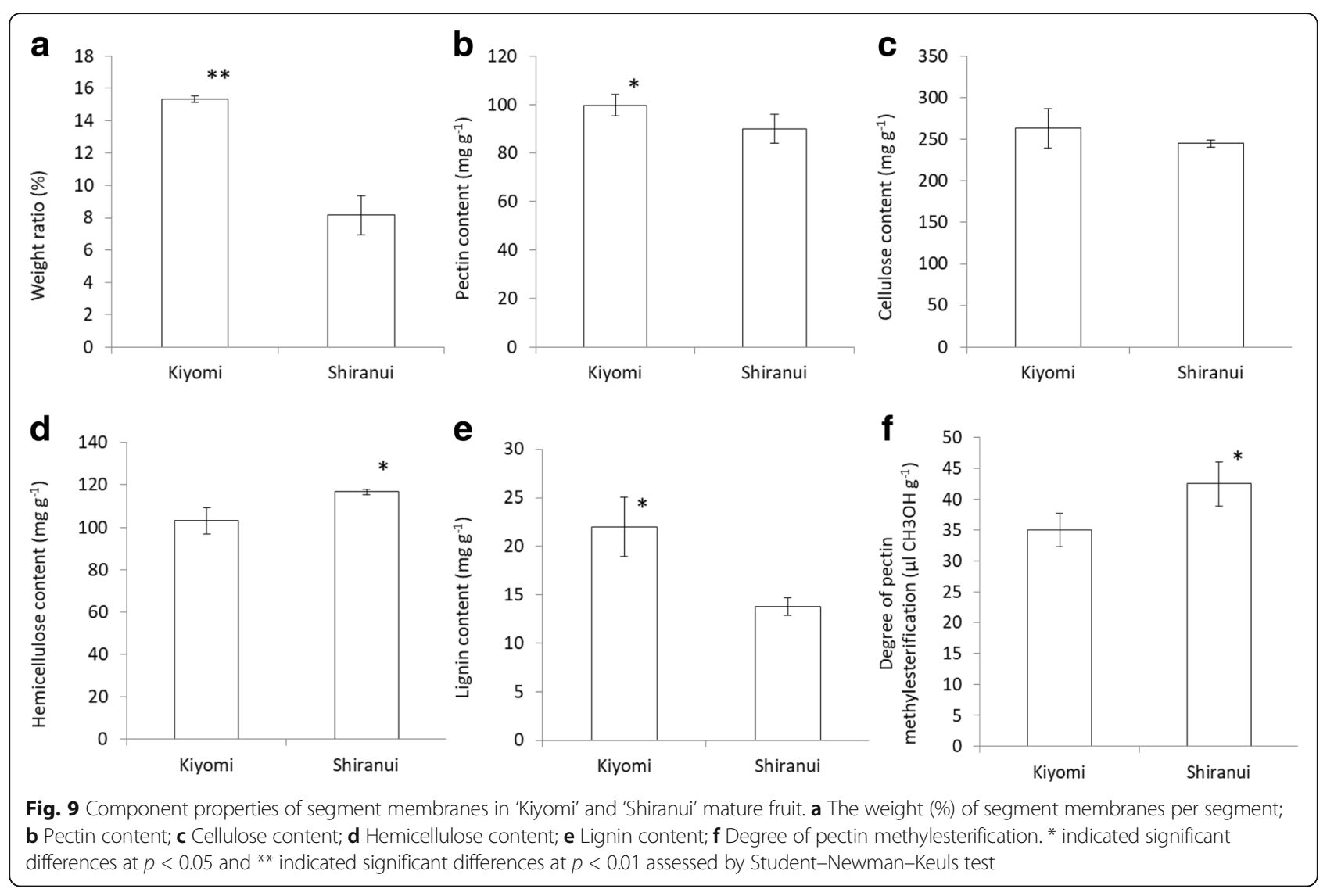

Segment membranes are not targeted in breeding but are edible portions of citrus. The popular consumerdriven sensory properties of citrus segment membranes are thin, soft and brittle. The property of thinness increases the enjoyment of eating the juice sacs, which are the contents of the segments, rather than the segment membrane. Desirable brittleness in citrus segment membranes allows them to be easily crumbled while chewing the juice sacs. The softness of segment membranes is preferred to a harsh texture.

The segment membrane' weight of 'Shiranui' was suspected to determine its thinness, making 'Shiranui' more pulpous. Pectin in plant cell walls is part of the polysaccharide network, which is involved in the control of cell wall porosity and cell expansion [70], and it is the major adhesive material between cells [71]. Adding pectin was suggested to improve food cohesiveness and, consequently, hardness and chewiness increased [72]. The greater amount of pectin in 'Kiyomi' segment membranes was surmised to impart its chewiness and decreased brittleness. Less esterified pectic polymers might also result in the decreased brittleness of 'Kiyomi' segment membranes because de-esterified pectin is susceptible to depolymerization, resulting in the increased viscosity of fruit paste [9] and, to some degree, citrus segment membranes that are less easily crumbled.
Lignin imparts strength and rigidity to plant walls, which are highly resistant to both mechanical disruption and enzymatic degradation [63, 73]. In animal nutritional tests, lignin and cellulose are undesired or "antinutritive" components because of their negative impact on nutrient availability [74] and palatability [75]. The harshness of foliage (as food) increases as the lignin and cellulose contents increase. The harsh taste in 'Kiyomi' results from the higher contents of these two components, particularly lignin, in segment membranes. Hemicellulose contains a diverse group of polysaccharides in plant cell walls. It has a random, amorphous structure that imparts little strength and is mostly soluble in aqueous solutions [55]. Accordingly, a higher hemicellulose content would not lead to a harsher taste for 'Shiranui'.

\section{Conclusions}

Our study provided a comprehensive transcriptomic insight into the citrus segment membrane's cell wall structures and metabolism, and indicated the possible contribution of segment membrane cell-wall composition to fresh citrus' organoleptic properties. The high repeatability of transcriptomic data and the detection of DEGs in 'Kiyomi' and 'Shiranui' indicated distinct differences during segment membrane development between the two citrus cultivars. A detailed transcriptomic analysis revealed 
potential critical genes involved in the metabolism of cell wall structures, for example, GAUT4 in pectin synthesis, CESA1, 3 and 6, and SUS4 in cellulose synthesis, CSLC5, $X X T 1$ and XXT2 in hemicellulose synthesis, and CSE in lignin synthesis. Low levels, or no expression, of genes involved in cellulose and hemicellulose, such as CESA4, CESA7, CESA8, IRX9 and IRX14, confirmed that secondary cell walls were negligible or absent in citrus segment membranes. A chemical component analysis in mature fruit segment membranes showed that higher pectin, cellulose and lignin contents might result in the undesired organoleptic properties of 'Kiyomi', which resulted in the fruit being perceived as thick, glutinous and chewy.

\section{Additional file}

Additional file 1: Figure S1. Heatmap of differentially expressing genes. Figure S2. Verification of RNA-seq by qRT-PCT. Figure S3. Top 30 significantly enriched pathways based on up-expressed genes in 'Kiyomi' compared with in 'Shiranui' at the first-stage. Figure S4. Top 30 significantly enriched pathways based on up-expressed genes in 'Shiranui' compared with in 'Kiyomi' at the first-stage. Figure S5. Top 30 significantly enriched pathways based on up-expressed genes in 'Kiyomi' compared with in 'Shiranui' at the second-stage. Figure S6. Top 30 significantly enriched pathways based on up-expressed genes in 'Shiranui' compared with in 'Kiyomi' at the second-stage. Table S1. Primers used in quantitative qRTPCR experiments. Table S2. Top 30 significantly enriched pathways based on up-regulated genes. Table S3. Genes involved in pectin metabolism. Table S4. Genes involved in cellulose metabolism. Table S5. Genes involved in hemicellulose (xyloglucans and xylan) metabolism. (PDF 808 kb)

\section{Abbreviations \\ 4CL: 4-coumarate:CoA ligase; C3H: p-coumaroyl shikimate 3-hydroxylase; C4H: Cinnamate 4-hydroxylase; CAD: Cinnamyl alcohol dehydrogenase; CCOAOMT: Caffeoyl CoA O-methyltransferase; CCR: Cinnamoyl CoA reductase; CEL: Cellulase; CESA: Cellulose synthase; COMT: Caffeic acid O- methyltransferase; CSE: Caffeoyl shikimate esterase; CSLCs: Cellulose synthase- like C proteins; DEGs: Differentially expressed genes; F5H: Ferulate 5- hydroxylase; FDR: False discovery rate; GATL: Galacturonosyltransferase-like; GAUT: Galacturonosyltransferase; GO: Gene Ontology; HCT: Hydroxycinnamoyl CoA:shikimate hydroxycinnamoyl transferase; HG: Homogalacturonan; IRX: Irregular xylem phenotype; PAL: Phenylalanine ammonia lyase; PC: Principal component; PME: Pectin methylesterase; SUS: Sucrose synthase; XXTs: Xyloglucans xylosyltransferases; XyGs: Xyloglucans; Xyls: Xylans}

\section{Acknowledgements}

We thank Dr. Lesley Benyon, from Liwen Bianji, Edanz Group China (www.liwenbianji.cn/ac), for editing the English text.

\section{Funding}

This work was supported by JunYuan Agricultural Co. Ltd., Suining, Sichuan, China for finance and plant materials collection.

\section{Availability of data and materials}

The datasets used and analyzed during the current study are available from either the first author or the corresponding author on reasonable request.

\section{Authors' contributions}

$X W, L L, Y T$ and $H X$ carried out all analyses and wrote the manuscript, $X C Z$, $\mathrm{MLY}$ and $\mathrm{XQ}$ conceived the experiment. $\mathrm{KX}$ and ZHW helped in the analyses. All authors read and approved the final manuscript.

\section{Ethics approval and consent to participate}

The sources of all fruit materials in this research were belonged to JunYuan Agricultural Co. Ltd., Suining, Sichuan, China, and no field permissions were necessary to collect the plant samples in this study. The collection of plant materials were complied with institutional, national, or international guidelines.

\section{Competing interests}

The authors declare that they have no competing interests.

\section{Publisher's Note}

Springer Nature remains neutral with regard to jurisdictional claims in published maps and institutional affiliations.

\section{Author details}

${ }^{1}$ Institution of Pomology \& Olericulture, Sichuan Agricultural University, No 211 Huimin Road, Wenjiang District, Chengdu 611130, Sichuan, China. ${ }^{2}$ Sichuan Horticultural Crop Agrotechnical Promotion Workstation, No 4 Wuhou Memorial Temple Street, Wuhou District, Chengdu 610041, Sichuan, China. ${ }^{3}$ College of Horticulture, Sichuan Agricultural University, No 211 Huimin Road, Wenjiang District, Chengdu 611130, Sichuan, China.

Received: 4 December 2017 Accepted: 13 April 2018

Published online: 23 April 2018

\section{References}

1. Nigel D, Kate G. Quality in citrus fruit: to degree or not degree. Brit Food J. 2002;104:492-505

2. Kohyama K, Nakayama Y Watanabe H, Sasaki T. Electromyography of eating apples: influence of cooking, cutting, and peeling. J Food Sci. 2005;70:S257-61.

3. Funami T. Next target for food hydrocolloid studies: texture design of foods using hydrocolloid technology. Food Hydrocoll. 2011;25:1904-14.

4. Szczesniak A. Classification of textural characteristics. Food Sci. 1963;28:385-9.

5. Fillion L, Kilcast D. Consumer perception of crispness and crunchiness in fruits and vegetables. Food Qual Prefer. 2002;13:23-9.

6. Van Buren JP. The chemistry of texture in fruits and vegetables. J Texture Stud. 1979;10:1-23.

7. Diane MB, John CB, Rob S. Color, flavor, texture, and nutritional quality of fresh-cut fruits and vegetables: desirable levels, instrumental and sensory measurement, and the effects of processing. Crit Rev Food Sci Nutr. 2010; 50:369-89.

8. Van Buggenhout S, Sila DN, Duvetter T, Van Loey A, Hendrickx M. Pectins in processed fruits and vegetables: part III-texture engineering. Compr Rev Food Sci F. 2009;8:105-17.

9. Waldron KW, Parker ML, Smith AC. Plant cell walls and food quality. Compr Rev Food Sci F. 2003;2:101-19.

10. Tisserat B, Galletta P, Jones D. Carpel polymorphism in citrus fruit. Bot Gaz. 1900;151:54-63.

11. Lim TK. Citrus reticulata 'Shiranui'. In: Lim TK, editor. Edible medicinal and non-medicinal plants: Volume 4, Fruits. Heidelberg: Springer; 2012. p. 732-8.

12. Weijers SR, Jonge JD, van Zanten V, Benedetti L, Langeveld J, Menkveld $H$, van Nieuwenhuijzen AF. KALLISTO: cost effective and integrated optimization of the urban wastewater system Eindhoven. Water Pract Technol. 2012;7:wpt2012036.

13. Robinson MD, McCarthy DJ, Smyth GK. EdgeR: a Bioconductor package for differential expression analysis of digital gene expression data. Bioinformatics. 2010;26:139-40.

14. Bateman A, Coin L, Dubin R, Finn RD, Hollich V, Griffiths-Jones S, Khanna A, Marshall M, Moxon S, Sonnhammer ELL, Studholme DJ, Yeats C, Eddy SR. The Pfam protein families database. Nucleic Acids Res. 2004:32:138-41.

15. Alexa A, Rahnenfuhrer J. topGO: enrichment analysis for gene ontology. $R$ package version 2.0. 2010. http://bioconductor.uib.no/2.7/bioc/html/topGO.html.

16. Xie C, Mao XZ, Huang JJ, Ding Y, Wu JM, Dong S, Kong L, Gao G, Li CY, Wei LP. KOBAS 2.0: a web server for annotation and identification of enriched pathways and diseases. Nucleic Acids Res. 2011;39:W316-22.

17. Minoru K, Goto S. KEGG: Kyoto encyclopedia of genes and genomes. Nucleic Acids Res. 2000;28:27-30

18. Livak KJ, Schmittgen TD. Analysis of relative gene expression data using realtime quantitative PCR and the 2- $\Delta \Delta C T$ method. Methods. 2001;25:402-8.

19. Taylor KACC. A colorirnetric method for the quantitation of galacturonic acid. Appl Biochem Biotech. 1993:43:51-4.

20. Wood PJ, Siddiqui IR. Determination of methanol and its application to measurement of pectin methyl ester content and pectin methylesterase activity. Anal Biochem. 1971;39:418-28. 
21. Fernandes JC, García-Angulo P, Goulao LF, Acebes JL, Amâncio S. Mineral stress affects the cell wall composition of grapevine (Vitis vinifera L.) callus. Plant Sci. 2013;205-206:111-20.

22. Bura R, Mansfield SD, Saddler JN, Bothast RJ. $\mathrm{SO}_{2}$-catalyzed steam explosion of corn fiber for ethanol production. Appl Biochem Biotechnol. 2002;98:59-70.

23. Atmodjo MA, Hao ZY, Mohnen D. Evolving views of pectin biosynthesis. Annu Rev Plant Biol. 2013;64:747.

24. Atmodjo MA, Sakuragi Y, Zhu X, Burrell AJ, Mohanty SS, Atwood JA, Orlandoa R, Scheller HV, Mohnena D. Galacturonosyltransferase (GAUT)1 and GAUT7 are the core of a plant cell wall pectin biosynthetic homogalacturonan: galacturonosyltransferase complex. Proc Natl Acad Sci U S A. 2011;108:20225-30.

25. Caffall DH, Pattathil S, Philips SE, Hahn MG, Mohnen D. Arabidopsis thaliana T-DNA mutants implicate GAUT genes in the biosynthesis of pectin and xylan in cell walls and seed testa. Mol Plant. 2009:2:1000-14.

26. Pelloux J, Rustérucci C, Mellerowicz EJ. New insights into pectin methylesterase structure and function. Plant Sci. 2007:12:267-77.

27. Micheli F. Pectin methylesterases: cell wall enzymes with important roles in plant physiology. Trends Plant. 2001;6:414-9.

28. Hyodo H, Terao A, Furukawa J, Sakamoto N, Yurimoto H, Satoh S, Iwai H. Tissue specific localization of pectin-Ca ${ }^{2+}$ cross-linkages and pectin methylesterification during fruit ripening in tomato (Solanum lycopersicum). PLoS One. 2013;8:e78949.

29. Somerville C. Cellulose synthesis in higher plants. Annu Rev Cell Dev Biol. 2006:22:53-78

30. Richmond T. Higher plant cellulose synthases. Genome Biol. 2000;1:30011-5.

31. Taylor NG, Laurie S, Turner SR. Multiple cellulose synthase catalytic subunits are required for cellulose synthesis in Arabidopsis. Plant Cell. 2000;12:2529-39.

32. Tanaka K, Murata K, Yamazaki M, Onosato K, Miyao A, Hirochika H. Three distinct rice cellulose synthase catalytic subunit genes required for cellulose synthesis in the secondary wall. Plant Physiol. 2003;133:73-83.

33. Desprez T, Juraniec M, Crowell EF, Jouy H, Pochylova Z, Parcy F, Hofte $H_{1}$ Gonneau M, Vernhettes S. Organization of cellulose synthase complexes involved in primary cell wall synthesis in Arabidopsis thaliana. Proc Natl Acad Sci U S A. 2007;104:15572-7.

34. Persson S, Paredez A, Carroll A, Palsdottir H, Doblin M, Poindexter P, Khitrov $\mathrm{N}$, Auer M, Somerville CR. Genetic evidence for three unique components in primary cell-wall cellulose synthase complexes in Arabidopsis. Proc Natl Acad Sci U S A. 2007;104:15566-71.

35. Brown DM, Zeef LAH, Ellis J, Goodacre R, Turner SR. Identification of novel genes in Arabidopsis involved in secondary cell wall formation using expression profiling and reverse genetics. Plant Cell. 2005;17:2281-95.

36. Persson S, Wei HR, Milne J, Page GP, Somerville CR. Identification of genes required for cellulose synthesis by regression analysis of public microarray data sets. Proc Natl Acad Sci U S A. 2005;102:8633-8.

37. Arioli T, Peng LC, Betzner AS, Burn J, Wittke W, Herth W, Camilleri C, Hofte H, Plazinski J, Birch R, Cork A, Glover J, Redmond J, Williamson RE. Molecular analysis of cellulose biosynthesis in Arabidopsis. Science. 1998:279:717-20.

38. Beeckman T, Przemeck GKH, Stamatiou G, Lau R, Terryn N, Rycke RD, Inze D, Berleth T. Genetic complexity of cellulose synthase A gene function in Arabidopsis embryogenesis. Plant Physiol. 2002;130:1883-93.

39. Burn JE, Hocart CH, Birch RJ, Cork AC, Williamson RE. Functional analysis of the cellulose synthase genes CesA1, CesA2, and CesA3 in Arabidopsis. Plant Physiol. 2002:129:797-807.

40. Desprez T, Vernhettes S, Fagard M, Refregier G, Desnos T, Aletti E, Py N, Pelletier $\mathrm{S}$, Hofte $\mathrm{H}$. Resistance against herbicide isoxaben and cellulose deficiency caused by distinct mutations in same cellulose synthase isoform CESA6. Plant Physiol. 2002;128:482-90.

41. Scheible WR, Eshed R, Richmond T, Delmer D, Somerville CR. Modifications of cellulose synthase confer resistance to isoxaben and thiazolidinone herbicides in Arabidopsis Ixr1 mutants. Proc Natl Acad Sci U S A. 2001;98: 10079-84

42. Nelmes BJ, Preston RD. Wall development in apple fruit: a study of the life history of a parenchyma cell. J Exp Bot. 1968;19:496-518

43. Haigler CH, Ivanova-Datcheva M, Hogan PS, Salnikov W, Hwang S, Martin K, Delmer DP. Carbon partitioning to cellulose synthesis. Plant Mol Biol. 2001; 47:29-51.

44. Coleman HD, Yan J, Mansfield SD. Sucrose synthase affects carbon partitioning to increase cellulose production and altered cell wall ultrastructure. Proc Natl Acad Sci U S A. 2009;106:13118-23.
45. Hayashi T, Yoshida K, Park YW, Konishi T, Baba K. Cellulose metabolism in plants. Int Rev Cytol. 2005;247:1-34.

46. Chou YH, Pogorelko G, Zabotina OA. Xyloglucan xylosyltransferases XXT1, XXT2, and XXT5 and the glucan synthase CSLC4 form Golgi-localized multiprotein complexes. Plant Physiol. 2012;159:1355-66.

47. Schmid M, Davison TS, Henz SR, Pape UJ, Demar M, Vin-gron M, Scholkopf B, Weigel D, Lohmann JU. A gene expression map of Arabidopsis thaliana development. Nat Genet. 2005;37:501-6.

48. Zabotina OA. Xyloglucan and its biosynthesis. Front Plant Sci. 2012;3:134

49. Cocuron JC, Lerouxel O, Drakakaki G, Alonso AP, Liepman AH, Keegstra K, Raikhel N, Wilkerson CG. A gene from the cellulose synthase-like C family encodes a-1,4 glucan synthase. Proc Natl Acad Sci U S A. 2007;104:8550-5.

50. Hamann T, Osborne E, Youngs HL, Misson J, Nussaume L, Somerville C. Global expression analysis of CESA and CSL genes in Arabidopsis. Cellulose. 2004;11:279-86.

51. Tucker MR, Koltunow AM. Traffic monitors at the cell periphery: the role of cell walls during early female reproductive cell differentiation in plants. Curr Opin Plant Biol. 2014;17:137-45

52. Zabotina OA, van de Ven WT, Freshour G, Drakakaki G, Cavalier D, Mouille G, Hahn MG, Keegstra K, Raikhel NV. Arabidopsis XXT5 gene encodes a putative alpha-1,6-xylosyltransferase that is involved in xyloglucan biosynthesis. Plant J. 2008;56:101-15.

53. Zabotina OA, Avci U, Cavalier D, Pattathil S, Chou Y-H, Eberhard S, Danhof L, Keegstra K, Hahn MG. Mutations in multiple XXT genes of Arabidopsis reveal the complexity of xyloglucan biosynthesis. Plant Physiol. 2012;159:1367-84.

54. Vuttipongchaikij S, Brocklehurst D, Steele-King C, Ashford DA, Gomez LD, McQueen-Mason SJ. Arabidopsis GT34 family contains five xyloglucan a-1, 6-xylosyltransferases. New Phytol. 2012;195:585-95.

55. Pauly M, Gille S, Liu LF, Mansoori N, Souza AD, Schultink A, Xiong GY. Hemicellulose biosynthesis. Planta. 2013;238:627-42.

56. Doering A, Lathe R, Persson S. An update on xylan synthesis. Mol Plant. 2012:5:769-71.

57. Faik A. Xylan biosynthesis: news from the grass. Plant Physiol. 2010;153: 396-402.

58. Scheller HV, Ulvskov P. Hemicelluloses. Annu Rev Plant Biol. 2010;61:263-89.

59. Lee C, Teng Q, Zhong R, Ye ZH. Molecular dissection of xylan biosynthesis during wood formation in poplar. Mol Plant. 2011:4:730-47.

60. Lee C, Zhong R, Ye ZH. Arabidopsis family GT43 members are xylan xylosyltransferases required for the elongation of the xylan backbone. Plant Cell Physiol. 2012:53:135-43.

61. Lee C, Zhong R, Ye ZH. Biochemical characterization of xylan xylosyltransferases involved in wood formation in poplar. Plant Signal Behav. 2012;7:332-7.

62. Boerjan W, Ralph J, Baucher M. Lignin biosynthesis. Annu Rev Plant Biol. 2003:54:519-46.

63. Bonawitz ND, Chapple $C$. The genetics of lignin biosynthesis: connecting genotype to phenotype. Annu Rev Genet. 2010;44:337-63.

64. Chen HC, Li QZ, Shuford CM, Liu J, Muddiman DC, Sederoff RR, Chiang VL. Membrane protein complexes catalyze both 4- and 3-hydroxylation of cinnamic acid derivatives in monolignol biosynthesis. Proc Natl Acad Sci U S A. 2011:108:21253-8

65. Betz C, McCollum GT, Mayer RT. Differential expression of two cinnamate 4-hydroxylase genes in 'Valencia' orange (Citrus sinensis Osbeck). Plant Mol Biol. 2001;46:741-8.

66. Vanholme R, Cesarino I, Rataj K, Yuquo X, Sundin L, Goeminne G, Hoon K, Cross J, Morreel K, Araujo P, Welsh L, Haustraete J, McClellan C, Vanholme B, Ralph J, Simpson G, Halpin C, Boerjan W. Caffeoyl shikimate esterase (CSE) is an enzyme in the lignin biosynthetic pathway in Arabidopsis. Science. 2013; 341:1103-6.

67. Lauvergeat V, Lacomme C, Lacombe E, Lasserre E, Roby D, Grima-Pettenati J. Two cinnamoyl-CoA reductase (CCR) genes from Arabidopsis thaliana are differentially expressed during development and in response to infection with pathogenic bacteria. Phytochemistry. 2001;57:1187-95.

68. Derikvand MM, Sierra JB, Ruel K, Pollet B, Do C, Thévenin J, BuVard D, Jouanin L, Lapierre C. Redirection of the phenylpropanoid pathway to feruloyl malate in Arabidopsis mutants deWcient for cinnamoyl-CoA reductase 1. Planta. 2008;227:943-56.

69. Sibout R, Eudes A, Mouille G, Pollet B, Lapierre C, Jouanin L, Séguina A. CINNAMYL ALCOHOL DEHYDROGENASE-C and -D are the primary genes involved in lignin biosynthesis in the floral stem of Arabidopsis. Plant Cell. 2005:17:2059-76. 
70. Mohnen D. Pectin structure and biosynthesis. Curr Opin Plant Biol. 2008;11:266-77.

71. Willats WGT, McCartney L, Makie W, Knox JP. Pectin: cell biology and prospects for functional analysis. Plant Mol Biol. 2001;47:9-21.

72. Skara N, Novotni D, Cukelj N, Smerdel B, Curic D. Combined effects of inulin, pectin and guar gum on the quality and stability of partially baked frozen bread. Food Hydrocoll. 2013;30:428-36.

73. Festucci-Buselli RA, Otoni WC, Joshi CP. Structure, organization, and functions of cellulose synthase complexes in higher plants. Brazil J Plant Physiol. 2007;19:1-13.

74. Moore KJ, Jung HJG. Lignin and fiber digestion. J Range Manag. 2001; 54:420-30.

75. Hardison WA, Reid JT, Martin CM, Woolfolk PG. Degree of herbage selection by grazing cattle. J Dairy Sci. 1954;37:89-102.

Ready to submit your research? Choose BMC and benefit from:

- fast, convenient online submission

- thorough peer review by experienced researchers in your field

- rapid publication on acceptance

- support for research data, including large and complex data types

- gold Open Access which fosters wider collaboration and increased citations

- maximum visibility for your research: over $100 \mathrm{M}$ website views per year

At BMC, research is always in progress.

Learn more biomedcentral.com/submissions 